\title{
A GEOGRAFIA DA CIDADE E DAS TRANSFORMAÇÕES URBANAS NA OBRA DE FIÓDOR DOSTOIÉVSKI: O ESPAÇO EM OS IRMÃOS KARAMÁZOV
}

\author{
GEOGRAPHY OF CITY AND URBAN TRANSFORMATIONS ON \\ FIÓDOR DOSTOIÉVSKI: SPACE IN THE KARAMÁZOV BROTHERS
}

\author{
LE GEOGRAPHIE DANS VILLE ET DES TRANSFORMATIONS \\ URBAINES AN OEUVRE DES FIÓDOR DOSTOIÉVSKI: \\ LE SPACE DANS LES FRÉRES KARAMÁZOV
}

Isis do Mar Marques Martins - Universidade Federal do Rio de

Janeiro - Rio de Janeiro - Rio de Janeiro - Brasil

isis.marinha@gmail.com

\begin{abstract}
Resumo
Dostoiévski foi o principal expoente da literatura russa, em um período de transformações socioespaciais no final do czarismo (final do século XIX e até 1917, com a Revolução Russa). Tal período marca a inserção da cultura ocidental até as reformas de urbanização e o processo de remodelagem do modo de produção, em que o campo e a cidade ainda dialogavam intensamente e a influência de uma cultura intelectual moderna desenhava uma cidade europeia incoerente aos padrões populares. Temáticas como migração campocidade, concentração fundiária, pobreza urbana e os cotidianos marcados pela desigualdade despontam, e é na literatura que a presença desta marca torna-se mais latente. Dessa maneira, o presente artigo visa compreender as transformações socioespaciais que motivaram e influenciaram as abordagens em Dostoiévski, dividindo-o em três partes: os aspectos históricos; as transformações culturais do berço da modernidade; e as relações entre os personagens e as transformações urbanas na obra Os irmãos Karamázov.

Palavras-chave: Geografia das cidades, transformações socioespaciais, Dostoiévski e a cidade.
\end{abstract}

\section{Abstract}

Dostoiévski was the main writer of the Russian literature, in a moment of sociospatial transformations in the final years of the Czarism (late nineteenth century to the 1917 Russian Revolution).Such period marks the insertion on Western culture and urbanization reforms and reshape of the mode of production, where the countryside and the city still had strong relations, and where the influence of an intellectual and modern culture draws an European city, incoherent to popular standards. Thematicsubjects, like field-city migration, land concentration, urban poverty and a daily life marked by inequalities, and these contradictions were highlighted on literature. On this way, this paper aims to comprehend the sociospatial transformations which motivated and influenced Dostoiévski approaches. It has three parts: historical aspects; modernity cultural transformations; and relationships between characters and urban transformations in The Karamázov Brothers. Keywords: Geography of cities, sociospatial transformations, Dostoievski and the city.

\section{Résumé}

Dostoievsky a été a le principal exposant de la littérature russe, dans une période de transformations sociospatiales à la fin du tsarisme (siécle XIX - 1917).Cette periode marque l'insertion de la culture occidentale et réformes de burbanisation, bien au processus de remodelage du mode de production, où la campagne et la ville étaient encore en dialogue étroit, et où l'influence d'une culture intellectuelle moderne concevait une ville européenne, incompatible avec les modèles populaires. Des thematiqués telles que la migration rural- 
urbaine, la concentration foncière, la pauvreté urbaine et les inégalités quotidiennes apparaissent, et c'est dans la littérature que la présence de cette marque devient plus latente. De cette façon, le présent article vise à comprendre les transformations socio-spatiales qui ont motivé et ont influencé les approches à Dostoiévski en divisant en trois parties: les aspects historiques; les transformations culturelles du berceau de la modernité; et les relations entre les personnages et les transformations urbaines dans le ouvre Les frères Karamázov. Mots clés: Geographie des villes, transfomations socio-spatiales, Dostoiévski et la ville.

\section{Introdução}

Uma das principais tarefas da geografia urbana é analisar e desvendar a natureza e o significado da rede urbana. Definida como produto da divisão territorial do trabalho, seu reflexo é a diferenciação espacial e a sua condição é a acumulação e a apropriação territorial conforme práticas de diferentes agentes produtores do espaço urbano (proprietários imobiliários, fundiários, Estado, movimentos sociais urbanos etc.).

Outra importante tarefa da geografia urbana é a análise dos ciclos de exploração da rede urbana, cujo principal ciclo é a relação capital e trabalho. Elas transitam no espaço e no tempo e promovem formas e conteúdos da cidade (Corrêa, 1989).

Podemos sintetizar, nesse sentido, três elementos para pensarmos a cidade, sua construção e suas transformações no espaço tempo. No primeiro elemento dar-se-á a funcionalização dos sistemas urbanos, depreendidos por Corrêa $(1989,2006)$ como interação necessária entre os agentes do espaço urbano e os processos urbanos em suas redes, mas também nos desdobramentos que implicam em sua função - dentre elas, as desigualdades espaciais. É o que dá classificação e suporta a análise da variação dos sistemas urbanos.

No segundo, a indissociação do espaço urbano com o espaço rural. É comum a crença de que o urbano sobrepõe o rural quando o processo é complementar. Capel (1975) aponta a necessidade de atravessarmos a barreira do urbano versus rural e nos atermos a sua formação calçada em um processo de contradições frutos da própria produção capitalista do espaço.

Terceiro, e não menos importante, o papel da geografia urbana em sistematizar e analisar os fenômenos que implicam na mudança do espaço urbano, desde sua morfologia até as implicações que contemplam a paisagem e os indicativos de formação de novos aparatos territoriais e 
regionais, seja pelas imbricações da desigualdade ou das formas urbanas. Os processos e as formas espaciais, tal como aponta Corrêa (1989), são também forças das quais a estrutura social se efetiva no espaço. Capel (1975) enfatiza a importância do olhar geográfico, sobretudo do geógrafo em sistematizar esse conhecimento da geografia urbana e destacá-lo também no contexto das ciências sociais.

A partir dessas três características de análise e reflexão do espaço urbano, a proposta do artigo é compreender a organização espacial da cidade a partir da leitura de um autor e de uma obra considerada clássica na literatura ocidental - não somente a partir de seu aspecto simbólico, advindo por si só da literatura. Nosso principal questionamento, vinculado ao que Bakhtin (2010) aponta como o caráter peculiar da polifonia de Dostoiévski, é desvendar o seu olhar espacial e crítico à cidade e aos fenômenos urbanos, sob um ponto de vista geográfico.

Esse caráter polifônico e essa leitura crítica da Rússia e de seus aspectos sociais e culturais são característicos das obras de Fiódor Dostoiévski, e nesse sentido uma apurada compreensão geográfica é também uma contribuição para pensarmos a geografia urbana como método de análise dos fenômenos passados, presentes e futuros enquanto processos complementares, intrínsecos ao que ocorre hoje.

\section{Dostoiévski e a cidade: relações e contextos}

Fiódor Mikháilovitch Dostoiévski nasceu em 30 de outubro de 1821 e morreu aos 60 anos, em 28 de janeiro de 1881. Viveu na consolidação do século XIX, cujas definições da sociedade russa foram marcadas pela ascensão do discurso urbano.

Os principais cenários de Dostoiévski fazem parte do cotidiano do próprio. Moscou e São Petersburgo foram ambientes de formação e vida do autor. Esse cotidiano, para além da história conturbada de sua infância (morte precoce da mãe e a figura severa e intempestiva do pai), sofre profundas transformações no curto período de vida de Dostoiévski. É importante em obras como Crime e Castigo, Niétotchka Niezvânova, Gente Pobre, O Idiota e, principalmente, Irmãos Karamázov, o contraste das reformas urbanas com a miséria das periferias está sempre presente, na mesma linha do pai severo, da mãe tísica e das gritantes diferenças das zonas rurais. É sempre nos personagens do interior do país que uma 
pureza e uma ingenuidade ascende e contrasta com a cadeia de crise e angústia de Moscou e/ou São Petersburgo.

Vale ressaltar que entre 1849 e 1854 ele foi preso e condenado à morte, tendo sua sentença substituída prestes à execução por cinco anos de trabalhos forçados na Sibéria. Essa parte de sua trajetória foi explorada em romances, nos quais o papel angustiante e contraditório da cidade são muito presentes, como em Crime e Castigo e Irmãos Karamázov, cujos protagonistas sofrem com a sensação das injustiças e agem como resposta a situações adversas que os levam a Sibéria.

Dentre os elementos desse discurso, destacam-se alguns levantados por Berman (1986): modernização subserviente, urbanização tardia, estrutura governamental-monárquica saturada, conflitos iminentes entre classes e, principalmente, o conflito entre o apelo da rigidez de uma moral por arquétipos modernos advindos dessa urbanização. Algumas questões são levantadas de forma bem sintomática em Tudo que é sólido se desmancha no ar, em face da Rússia - São Petersburgo sobretudo, capital do czarismo russo no então século XIX.

O contraste entre Dostoievski e Baudelaire, e entre Paris e Petersburgo na metade do século XIX, deve nos ajudar a ver uma polaridade maior na história mundial do modernismo. Num pólo, podemos ver o modernismo das nações avançadas, brotando diretamente da modernização política e econômica e obtendo visão e energia de uma realidade modernizada, mesmo quando desafia essa realidade de forma radical. No pólo oposto, encontramos um modernismo que emerge do atraso e do subdesenvolvimento. Esse modernismo surgiu pela primeira vez na Rússia, mais dramaticamente em São Petersburgo, no século XIX; em nossa era, com o avanço da modernização - porém, geralmente, de uma forma trancada e desvirtuada como na antiga Rússia -, expandiu-se por todo o Terceiro Mundo. O modernismo do subdesenvolvimento é forçado a se construir de fantasias e sonhos de modernidade, a se nutrir de uma intimidade e luta contra miragens e fantasmas (Berman, 1986, p. 219).

Esse conflito gerado sob a profunda desigualdade da modernização dos espaços, cuja lógica veio de fora da Rússia - o que acarretou tensionamentos entre as diversas classes da época -, refletiu-se entre os intelectuais, destacando-se os escritores e críticos literários, cuja principal característica era a necessidade de ressaltar a identidade russa, definidas pela rigidez, muito influenciados pela ortodoxia religiosa. Nesse sentido, 
os intelectuais estavam entre os eslavófilos, mais conservadores quanto a essa matriz identitária russa, e os ocidentalistas, que compreendiam que a modernização da sociedade promoveria novas configurações necessárias ao país.

Apesar de diferenças individuais de estilo e método, é possível descrever uma pauta conjunta eslavófila sem que isso implique generalizações excessivas. Já o ocidentalismo é um nome "guarda-chuva" que abriga projetos muito distintos para a sociedade russa, alguns até incompatíveis, unidos pela amplíssima ideia de que era necessário integrar (ou reintegrar) a Rússia à vida europeia: seria possível fazê-lo por meio da revolução social, de reformas políticas, de tendências liberais, de grandes saltos culturais e morais, e inclusive a partir de um prisma religioso (Gomide, 2013, p. 17).

É salutar também apreender o momento em que os posicionamentos - o moderno e o tradicional - se enfrentavam. Estamos falando do último século do chamado czarismo, em uma espacialidade ampla e diversa. A Rússia compreende grande porção da Europa e da Ásia, e geopoliticamente é essencial para vários países do mundo. Três momentos são importantes para entender a decadência do feudalismo russo no século XIX e do czarismo no início do século XX.

Primeiro, a invasão por Napoleão em 1812 e a vitória russa, sobretudo pelo frio que dizimou grande parte dos militares franceses ${ }^{1}$. A vitória russa trouxe certo status ao país no cenário das potências europeias, atraindo investimentos aos grandes proprietários rurais. Estes proprietários, influenciados pelas ideias do capitalismo industrial ascendente, investiam cada vez mais na maquinofatura, destituindo uma classe de mão de obra que ainda nesse período era legalmente serva, isto é, não tinha o direito à propriedade - privilégio hereditário - e à renda, a não ser o que era definido pelo proprietário. O conflito entre servos e proprietários - o segundo grupo apoiado pelo governo czarista - tornou-se mais latente quando a consolidação das fábricas, bem como a construção de linhas ferroviárias para o escoamento da produção agrícola e manufatureira, não consolidou a melhoria da qualidade de vida da classe mais pobre russa.

Segundo, a Guerra da Criméia na metade do século XIX desnudou as fragilidades encadeadas pelo pouco investimento no desenvolvimento da Rússia frente a países cuja modernização via capitalismo industrial conotava o que seria definido por grandes potências europeias. Na tentativa de reforçar o império czarista, o governo russo então ocupou os Estreitos 
de Bósforo e Dardanelos, no litoral turco, local estratégico no Oriente Médio. Inglaterra e França se opuseram à ocupação russa e foi deflagrada a guerra que ocorreu entre 1853 e 1856. A Rússia, despreparada para um conflito marítimo, perdeu e sofreu consequências como proibição da comercialização e navegação pelo Mar Negro.

Terceiro, em consequência da derrota na Guerra da Criméia, se acentuou mais ainda a deterioração do governo czarista, culminando em várias revoltas contra as decisões cujo interesse dos grandes proprietários dizimava o restante da população. Para apaziguar parte dessas revoltas, foi promulgada em 1861 a abolição da servidão.

Nesse sentido, esses três momentos transcorrem pela transformação tanto do espaço urbano quanto do espaço rural no país, cujo desenvolvimento das cidades - tal como apontamos com Bermam (1986) - foi desigual por um modelo externo, sem referências às contradições e aos conflitos da Rússia, e combinado conforme as elites e os proprietários aportados pelo governo feudal. Um urbano nascido de uma lógica précapitalista, cuja ordem e lógica não nascem da própria fonte.

A literatura e a intelectualidade russa da época, diante das contradições advindas do processo de transformação de sua sociedade, destacaram tais elementos conforme seus interesses. Se os eslavófilos promoviam o discurso do tradicionalismo, os ocidentalistas em geral entendiam a modernização de ambos os lados.

O ponto é que Dostoiévski, que não veio da classe nobre nem da servidão, compreendeu esse processo a partir da sociedade em conflito, sobretudo com sua própria ideia de nação e de identidade nacional ou com o novo modelo de modernização, refletidos na transformação das cidades ora pela pobreza e pelo êxodo rural, ora pela máquina monárquica defasada e construindo novos artefatos urbanos vinculados a uma belle époque inexistente (Berman, 1986). Conforme Mikhailóvski (2013), após a morte de Dostoiévski:

A ortodoxia soviética nunca soube bem o que fazer com Dostoiévski. Ele não podia ser simplesmente riscado do mapa, pois já assumira uma posição simbólica que ia muito além dos textos publicados. Por outro lado, era um elemento incômodo dentro da perspectiva "clássica", em que se enquadravam mais confortavelmente nomes como o de Tolstói. A solução foi morder e assoprar, mantendo-o no tenso equilíbrio entre genialidade e doença. Talento e crueldade (Mikhailóvski, 2013, p. 437). 
Esse olhar crítico à sociedade russa foi uma das principais marcas dos personagens do autor. Dentre todas as características apontadas pela poética de Dostoiévski, podemos salientar duas que convergem com o olhar crítico não só produzido pela realidade contraditória, mas de uma sociedade em conflito.

A primeira característica é o que Bakhtin (2010) tratará pelo caráter polifônico das obras do escritor, entendendo as multiplicidades de discurso presentes em suas obras, que promovem uma série de opiniões, e na maioria das vezes divergentes entre os personagens. Em um primeiro momento, parece incompreensível ou até pouco óbvia essa característica, mas analisando a fundo o processo de construção de um romance, e as influências presentes entre o autor e a obra, encontrar personagens que opinam e sentem valores, ideias e posicionamentos divergentes é um trabalho deveras minucioso para qualquer escritor.

A multiplicidade de vozes e consciências independentes e imiscíveis e a autêntica polifonia de vozes plenivalentes constituem, de fato, a peculiaridade fundamental dos romances de Dostoiévski. Não é a multiplicidade de caracteres e destinos que, em um mundo objetivo uno, à luz da consciência uma do autor, se desenvolveu nos seus romances; é precisamente a multiplicidade de consciências eqüipolentes [consciências e vozes em pé de absoluta igualdade] e seus mundos que aqui se combinam numa unidade de acontecimento, mantendo a sua imiscibilidade (Bakhtin, 2010, p. 5).

Uma segunda característica importante de seus personagens é o ambiente provocador, as situações de emergência próprias de seus personagens, que os elevam ao limite da cidade, do espaço. A crueldade e a angústia, sintomáticas dessa emergência, são muitas vezes reflexo do limiar entre o público e o privado, entre a angústia da pobreza e da miséria com o apelo da burocracia estatal, presentes nos conflitos da sociedade russa do século XIX. A crueldade apontada é latente, pois evidencia e ambienta as problemáticas da urbanização desigual. Berman (1986) ressalta essa latência no romance Gente pobre, escrito em 1846.

O funcionário de Dostoievski teme apenas duas coisas: de um lado, que "alguma duquesa ou condessa", a classe dominante que governa a vida da rua e a vida cultural, se ria dele, de seus sapatos remendados, de sua alma esfarrapada; de outro - e isso provavelmente seria ainda pior - , que seus superiores nem se apercebam de suas solas (“afinal de contas, há sapatos e sapatos”) ou de sua alma. Qualquer 
uma dessas possibilidades pode de fato ocorrer: o funcionário não pode governar as respostas dos governantes. Aquilo que realmente cai sob sua jurisdição é seu próprio auto-respeito: seu "senso de dignidade pessoal, de egoísmo necessário”. [...] Nesse momento, 1845, nenhum russo, real ou ficcional, pode imaginar concretamente como isso poderá ocorrer. Todavia, Gente Pobre pelo menos define o problema - um problema crucial na política e cultura russa - e possibilita aos russos da década de 1840 imaginar que a mudança ocorrerá, de alguma forma, algum dia (Berman, 1986, p. 200).

Dentro das perspectivas apontadas de Dostoiévski, ressaltamos a obra Os irmãos Karamázov por algumas razões. Dentre elas, é consenso tanto dos críticos quanto do próprio Dostoiévski a importância deste livro enquanto síntese de seu pensamento. É também n'Os irmãos Karamázov que a consolidação do espaço urbano moderno se destaca, em concomitante aos seus personagens cujo teor crítico de seus discursos também aporta e salienta a reflexão geográfica a partir do espaço como principal elemento de compreensão da sociedade.

\section{Os Irmãos Karamázov - A cidade e a obra}

Os irmãos Karamázov foi escrito por Dostoiévski a fim de sintetizar sua ideia de homem e moral, em profunda transformação na Rússia. A história, em linhas gerais, narra os conflitos da família Karamázov diante da acusação de parricídio de Fiódor Pavlólvith pelo filho Dimitri Karamázov. Dentre as peculiaridades desta família, os símbolos apresentados compartilham o cenário de São Petersburgo como capital do império czarista e de suas influências versus o capitalismo em ascensão, sobretudo com os novos atores deste processo, que envolveu boa parte das décadas de 1860 e 1870.

Ao que tudo indica, há dois elementos que condizem com as mudanças da cidade para urbano conforme as transformações contemporâneas no final do século XIX. Em primeiro lugar, o autor define os personagens como atores que representam essa transformação na ordem social e socioespacial. Em segundo lugar, o espaço em si dos acontecimentos, e mesmo a insurgência aleatória de outros espaços na trama - o que era comum vide o caráter de urgência dos acontecimentos em Dostoiévski - apontam elementos importantes que visam apreender o movimento da sociedade em questão. 
A história narra o encontro entre os membros da família Karamázov, destacando-se os reflexos da displicência da criação do pai - cuja riqueza provinha de heranças e posses de terras antigas - para com os filhos, criados ou por uma família, ou pelos monges ortodoxos russos, ou pelos empregados do pai. Adiante, no tema central da ausência, vale ressaltar a descrição detalhada de todos os personagens principais, cujos papéis acompanham a transformação da sociedade russa tanto nas cidades quanto nas zonas rurais, e principalmente o choque cultural entre essas transformações.

Ressalta-se o contexto de criação do romance para o autor. Dostoiévski aproveitou uma acusação real de parricídio por um filho impulsivo chamado Dmitri Ilinski e que alardeava o ódio pelo pai. Após a sentença condenando o mesmo e depois de preso por algum tempo, foi inocentado na descoberta do verdadeiro assassino. De acordo com Bezerra:

Muitos dos traços do caráter de Dmitri Ilinski - esbanjador incontrolável, beberrão, pândego, desrespeitoso com o pai, assim como a elevada autoestima, a honestidade e certa ingenuidade -, coincidem com aspectos do comportamento de Dmitri Karamázov. Mas o protótipo, uma vez transformado em personagem, deixa de ser um caso particular e amplia-se como representação de uma categoria sócia. Assim, áqüea condição de esbanjador incontrolável e pândego de Dmitri Ilinski caracteriza, em Dmitri Karamázov, um hábito típico de uma classe social: a nobreza (Bezerra, 2009, p. 10).

Isto implica que não somente os espaços dos acontecimentos preponderam nessas transformações, mas que os próprios personagens transformam-se em espaços de acontecimento. Se é em Dmitri que o impulsivo, o desrespeito quase jovial se demonstra (como a nobreza singular do czarismo russo, pândega pela exploração socioespacial), seu pai, Fiódor Pávlovitch, é a nobreza rural em decadência, no qual a exploração pela usurpação já não é mais suficiente para um status de riqueza. O capitalismo, portanto, ascende.

Outros dois personagens importantes para compor as contradições dos acontecimentos do espaço de criação do romance são Ivan e Alieksiêi Karamázov, irmãos de Dmitri e filhos mais novos de Fiódor. O primeiro, criado por um intelectual cosmopolita, possui ideais e perspectivas opostas à sociedade rígida e cristã russa, e reflete a mudança intelectual ainda em crise com as novas proposições ora positivistas, ora economicistas, ora marxistas. A laicização do Estado moderno consolidado em boa parte 
da Europa, em contradição à sociedade feudal russa, entra em conflito e incoerência, e adoece, tal como ocorre com o personagem quando retorna à Rússia após obter certo prestígio com um polêmico artigo que indica o caráter político da existência de Deus. Eis assim, a famosa frase deste personagem: "Não existe a imortalidade da alma, então, não existe tão pouco a virtude. Logo, tudo é permitido” (Dostoiévski, 2009, p. 127).

O segundo e caçula Aliócha (diminutivo russo de Aleksiêi) é o protagonista do romance, cunhado pelo próprio autor de herói da novela. Uma característica comum aos "heróis" de Dostoiévski é o descrédito no diálogo com qualquer outro personagem da trama, como se no protagonista houvesse uma ingenuidade e inocência em suas palavras. Tais personagens representam o singelo da vida da sociedade em geral, a voz trazida das classes mais pobres da Rússia, seja dos centros urbanos ou dos grupos nas propriedades rurais. Em contraponto ao singelo, a importância dada a esse protagonista e suas relações com as crianças e com o sofrimento e resignação às crianças pobres esclarece esse papel. Outra característica deste é a devoção literal à ortodoxia cristã, característica também deste tipo de personagem pelo autor.

Aliócha reúne em si um amor ativo pelo ser humano e a capacidade de não apenas compreender, mas de compenetrar-se dos problemas dos outros, de vivenciá-los com eles. Graças à grande elasticidade de sua natureza e à extraordinária capacidade de penetrar nos desvão da alma humana, todos acreditam em Aliócha e assim ele exerce a condição de mediador entre todas as personagens do romance, que, em momentos de crise, sempre encontram nele a pessoa que sabe ouvir com atenção e paciência e emitir opiniões ponderadas, como se temesse ferir o outro com sua palavra (Bezerra, 2009, p. 14).

Quanto ao segundo elemento, o espaço dos acontecimentos em si e seu caráter de urgência está imbricado no espaço do romance, que além de visualizar pela Rússia em conflito com suas ruralidades, é paradoxalmente também sua sociedade que promove a reforma urbana. O autor aponta com clareza, tanto nesta obra como em outras, as diversas construções influenciadas pela arquitetura francesa, como a construção de pontes e outras formas de embelezamento da cidade. Também, na discussão com personagens, sem sair da polifonia, na concordância com as novas formas urbanas entre um personagem cosmopolita e um personagem russo conservador discordando do caráter e da importância da propriedade rural. 
É sobretudo na perspectiva socioespacial, na interação entre espaço e sujeito, que a formação do imediato nos seus romances se institui, como que se a todo espaço e na trajetória para com a cidade russa os personagens encontrassem obstáculos. É no sentido de urgência dos acontecimentos, no caráter dessa urgência. Vale as palavras de Gilles Deleuze em alusão:

Em Dostoiévski, os personagens são perpetuamente vítimas da urgência e, ao mesmo tempo em que eles são vítimas dessas urgências, que são questões de vida ou morte, eles sabem que há uma questão ainda mais urgente, embora não saibam qual. E é isso que os paralisa. Tudo se passa como se, na maior urgência - "É um incêndio, é preciso que eu vá" —, eles se dissessem: "Não, existe algo ainda mais urgente. Não moverei um dedo até saber do que se trata”. É “O Idiota” (romance de Dostoiévski filmado por Kurosawa). É a fórmula de "O Idiota": "Veja, há um problema mais profundo. Qual problema, não saberia dizer ao certo. Mas me deixe. Tudo pode arder... É preciso encontrar esse problema mais urgente” (Deleuze, 1983, p. 187).

Como apontado, a reflexão dostoievskiana conflita com a matriz da intelectualidade e dos pensadores literatos de sua época, que firmavam a importância da identidade nacional e a necessidade de reforçá-la. Na tentativa de contrapor o telúrico do sentido da sociedade fundiária, crucial para a concepção de uma sociedade feudal russa, o espaço e a emergência são os cruzamentos que incidem e muitas vezes alertam a importância do cosmopolitismo, da diversidade e da pluralidade, constructos principais na produção de espaços, quiçá cidades.

Ao mesmo tempo, o acontecimento e a superação destes para com a narrativa implodem na necessidade de vislumbrar o contraditório da sociedade, isto é, de visualizar que a imensa maioria de seus sujeitos não participa ativamente da construção daqueles espaços. Nesse sentido é que a contribuição do autor e dessa obra são importantes para a reflexão dos processos socioespaciais constituintes na formação de cidades e que revelam todo o escopo de produção do espaço.

\section{A geografia das cidades em Dostoiévski: espaço-tempo e as realidades cruzadas}

A constituição das cidades envolve um processo lento e gradual de transformação do homem e do espaço em que ele vive, tal processo torna-se muito vinculado ao nível de autonomia humana frente à natureza. 
A inversão da dependência do homem frente à natureza é sem dúvidas o motor da transformação dos espaços, a sua organização em cidade.

A consistência das cidades, seja na pré-história até ao grau máximo do processo de urbanização (Lefebvre, 1999), no qual a construção das cidades é partícipe de um projeto urbano, descolado da sociedade e inteiramente vinculado ao sistema capitalista, envolveu em diferentes níveis a desigualdade e a hierarquia social. Se tomarmos como medida cidades como Roma e Atenas, a base ocidental da formação das sociedades modernas, a divisão piramidal e a pobreza eram o motor da chamada democracia, as quais se viam presentemente em suas cidades. Dessa maneira, Lefebvre (1999) evidencia quatro tipos de cidades precedentes à industrialização: a cidade-Estado da antiguidade, a cidade oriental, a cidade arcaica e a cidade medieval.

Conforme ainda, há uma ruptura entre a formação da cidade política até a inflexão do agrário para o urbano, coincidindo com a formação da cidade renascentista e a pulverização do predomínio das relações agrárias. A inflexão do rural para o urbano trouxe uma série de perspectivas para o espaço de construção das relações sociais da época. A expansão do racionalismo cartesiano colaborou para a renovação da cidade como pensada e planejada, donde a troca e o mercado se inserem intrinsecamente.

No século XIV, senhores e burgueses edificam cidades mercantis nas regiões incultas, quase desérticas. A cidade mercantil tem seu lugar, no percurso, depois da cidade política [...] Num determinado momento, no Ocidente europeu, tem lugar um 'acontecimento'. $\mathrm{O}$ peso da cidade no conjunto social torna-se tal que o próprio conjunto desequilibra-se. A relação entre a cidade e o campo ainda confere primazia a este último. Num dado momento, essas relações múltiplas se invertem [...] ela não aparece mais como um paradoxo, monstro, ela entra na consciência e no conhecimento como um dos termos, igual ao outro, da oposição cidade -campo. Produzem para a cidade, para o mercado urbano (Lefebvre, 1999, p. 20-21).

Ainda que a presença da cidade se modifique para o racionalismo moderno e o capitalismo industrial, o processo de disseminação e constituição das cidades era promovido por duas frentes que se relacionam entre si: a necessidade de alijar e promover a cidade-deslumbramento, iluminada e aberta que demonstra a riqueza de suas trocas, e a interrupção da funcionalização para as classes mais pobres, ratificando que estes não 
eram bem-vindos à cidade, a não ser para cumprir sua função como corpo do trabalho, como força de trabalho.

Nessa perspectiva, a contribuição de Karl Marx (2013) ao entendimento das transformações do espaço urbano é basilar. Para ele, a nobreza feudal criou mecanismos de expulsão do usufruto da terra pelos camponeses a fim de solidificar a produção para a manufatura a partir da transformação do uso da terra da agricultura para a pecuária extensiva.

O Estado, por sua vez, legitima a destituição das terras por meios ilícitos, consolidando sua soberania aos interesses das novas classes que viviam da barganha, como a burguesia. A usurpação das terras comunais foi uma das causas cruciais da expulsão de trabalhadores do campo para a cidade, já que extraiu sua garantia de renda no campo.

O roubo dos bens da Igreja, a alienação fraudulenta dos domínios estatais, o furto da propriedade comunal, a transformação usurpatória, realizada com inescrupuloso terrorismo, da propriedade feudal e clânica em propriedade privada moderna, foram outros tantos métodos idúlicos da acumulação primitiva. Tais métodos conquistaram o campo para a agricultura capitalista, incorporaram o solo ao capital e criaram para a indústria urbana a oferta necessária de um proletariado inteiramente livre (Marx, 2013, p. 979).

É David Harvey (2005) quem ressalta, a partir de Marx (2013), que o espaço nesse ínterim é fundamental na ideia da acumulação primitiva. O caráter geopolítico dessa acumulação se impõe, isto é, o papel dos Estados em expropriar terras e força de trabalho concomitante à dominação pela expansão territorial de sua influência e exploração nas Américas, na África e na Ásia.

Assim nascem cidades como Paris e Londres. Coloridas e iluminadas, monumentais e principalmente multiterritoriais para quem oferece e pode usufruir seus deslumbres. O urbano se consolida e a cidade como obra sucumbe ao projeto capitalista de plano urbano, traço urbano e funcionalidade para o capitalismo. Alijados e sem o poder do usufruto pleno do urbano, os de baixo são paulatinamente expulsos dos chamados centros de decisão, formando suas redes dependentes a este, sem muitas escolhas e possibilidades de produzir seus próprios planos e cidades.

Ainda conforme Corrêa (2006), a constituição das redes urbanas envolve formas espaciais que promovem e são promovidas por determinadas frentes de atuação. Logo, as áreas centrais são planejadas conforme o interesse de determinados agentes, sobretudo os agentes dos 
centros de decisão, em transformar espaços em localidades centrais. Em apoio à teoria das localidades centrais de Christaller (1966), Corrêa (1989, 2006, 2010) apreende a dialética marxiana para propor o caráter crítico à formação de redes urbanas vinculadas a lógica do capitalismo.

Nesse sentido, o Estado e o mercado, em sua grande medida, se aliam para produzir o espaço urbano em diversas frentes. Mas qual afinal a relação entre a produção da cidade, a produção do espaço urbano e finalmente a constituição das redes urbanas? A análise precisa de Souza (2011) de lembrar dois aspectos fundantes da cidade: um, ela nasce da necessidade de escoamento da produção e dois, ela cresce pela diversidade do mercado, da decisão do Estado e principalmente de seu crescimento diversificado, isto é, a morada da cidade torna-se não somente de quem é atrelado ao mercado ou funcionário do Estado. É morada da população pobre e das demais esferas da sociedade. Esse aprimoramento e diversificação do espaço urbano é o que produz paulatinamente uma análise sofisticada e complexa.

Nesse sentido, a obra de Dostoiévski enriquece a perspectiva crítica da cidade, sobretudo de todo o processo confuso e sobreposto da formação do urbano nas principais cidades russas. A camada da população rural ou suas ruralidades nas cidades como Moscou e São Petersburgo, conforme foi apontado, se choca com o travestimento de urbano traçado pela exportação do urbano parisiense e londrino. Mas vale ressaltar que toda a relação política, econômica e social denota um feudalismo tardio da Rússia do século XIX.

A seguir, no diálogo entre Aliócha e Dmitri, a tentativa de explicar as diferentes cidades - a moral e a dos becos - que incidem sobre essas transformações e promovem essas contradições que mesclam o espaço narrado pelo autor quanto ao intrínseco do espaço na constituição dos próprios personagens. Dmitri, nesse sentido, se opõe ao deslumbre da cidade e aponta caminhos do que naquele momento era o lado negativo da cidade, que deixara paulatinamente de existir à construção de praças e avenidas. Os becos escuros são substituídos pelos becos morais e ele, como avesso aos últimos - por ser Karamázov - se alimenta da cidade adversa à nova cidade:

Eu sempre gostei de becos, de recantos desertos e escuros, atrás da praça - lá estão as aventuras, as surpresas, lá estão as pepitas do lodo [...] Aqui em nossa cidadezinha nunca houve esses becos concretos, mas houve becos morais. Se, porém, tu fosses o que eu 
sou, compreenderias o que isso quer dizer. Eu gostava da devassidão, gostava da desonra da devassidão. Gostava da crueldade: por acaso eu não sou um percevejo, não sou um inseto perverso? Está dito Um Karamázov! (Dostoiévski, 2009, p. 164)

Dostoiévski esperava sintetizar em Irmãos Karamázov toda uma crítica e todas as características plurais da sociedade russa em uma obra que contemplasse exatamente esse choque de realidades e pensamentos, mas que os mais representantes desse conflito fossem os próprios personagens, com atributos e características do espaço em processo de ruptura.

Nesse aspecto, vale lembrar que a formação das redes urbanas, conforme Corrêa (2006) e complementado por Souza (2011), se justifica pela evolução do espaço urbano em ascensão a própria lógica capitalista. Por que, então, dá-se nesse ensaio tanta importância às redes urbanas se a Rússia czarista era considerada pré-capitalista?

Ora, embora a Rússia e cidades que hoje são consideradas grandes metrópoles, como Moscou, tivessem incoerências diversas a formação de suas cidades (e a principal é o arranjo espacial ser modificado eminentemente pelos empresários modernistas russos) e à política com reminiscências feudais, a própria discussão que aqueceu o século XIX foi a necessidade de inserir a Rússia ao cenário europeu desta mesma escala de tempo, cujo capitalismo industrial já havia sido consolidado e que relatado em vários trechos de Os Irmãos Karamázov - ascendia uma nova potência do capitalismo financeiro, os Estados Unidos.

Dostoiévski, nesse sentido, em vários momentos da obra permite dialogar com essas incoerências quando calorosamente promove discussões entre os financeiristas judeus (de forma extremamente pejorativa, inclusive), os socialistas em ascensão e os formadores de opinião eminentes nas cidades, os aristocratas em decadência, os pobres em crise com a cidade, no qual participam de forma sempre urgente, angustiante e muitas vezes trágica, com intelectuais cristãos e muitos, muitos outros. Ele o tempo todo mostra essa multiplicidade do espaço urbano, com a qual sempre lidamos nas leituras de geografia urbana.

Depreendem-se três aspectos principais da geografia urbana, que são precisamente compatíveis à reflexão da Rússia sob a ótica dostoievskiana: primeiro, a produção do espaço urbano e suas complexidades a partir de sua própria formação, em incoerência ao Estado feudal-tardio descolado 
da burguesia em angústia com o capitalismo consolidado do restante da Europa; segundo, a formação das duas principais cidades em angústia na decisão de deixar de lado suas ruralidades e assumir-se urbana frente aos novos cenários; terceiro e o mais importante, a angústia das classes baixas (plurais de fato) em assumir parte dessa cidade, quando ela mesma é descolada de sua produção, da mesma forma que o descolamento da produção de seus espaços era assunção da obra czarista.

Portanto, abre-se um caminho de interpretação do espaço que possibilita a crítica via obras clássicas da literatura, vislumbrando não somente a descrição da paisagem, mas a apreensão do papel do geógrafo em promover o espaço analítico, em ocasião o espaço urbano, tal como ressaltado por Capel (1975). Sem necessariamente mexer com o prisma e o papel fundamental da obra, mas compreendendo nesse papel a importância do espaço e da suas ferramentas de análise enquanto categoria da ciência geográfica na contemporaneidade.

\section{Considerações Finais}

Para além de caracterizar e descrever momentos e ideias, as narrativas literárias, sobretudo as chamadas clássicas, intervém em processos de ruptura de uma determinada sociedade. Tais narrativas também revolucionam a ideia e o conceito de determinados contextos de produção de determinadas tessituras sociais.

O presente artigo procurou, nesse contexto, apreender os cruzamentos possíveis de uma narrativa literária em um autor cujas características direta ou indiretamente envolvem a produção crítica de uma sociedade, que muitas vezes o leva ao choque ideológico promovido por interesses presentes, como no caso da identidade russa, e a análise geográfica, sobretudo aos acontecimentos da cidade.

Assim, ressaltam-se três principais elementos de relação entre a obra Os irmãos Karamázov e a Geografia:

1 - O papel do choque de ideias a fim de apreender as transformações espaciais: é na polifonia do autor assimilado na crítica à identidade e principalmente à identidade nacional que a cidade russa na literatura dostoievskiana ascende enquanto problemática, e cujos elementos geográficos mais se despontam. As imbricações entre política, sociedade e cultura trazem à tona a transformação dos elementos da sociedade 
russa profundamente marcada pela desigualdade, em um capitalismo que interfere nas tomadas das decisões políticas de uma nobreza letárgica pelo feudalismo tardio. Espaço e tempo tornam-se presentificados e marcados tanto pelo espaço dos acontecimentos da narrativa quanto na presença do espaço-sujeito, no qual a polifonia do autor é mais notada e mais cruzada com uma análise geográfica;

2 - Os acontecimentos reais que envolvem autor, obra e cidade e suas marcas no futuro: o século XIX foi de transição do final do czarismo russo para a Revolução Russa em 1917, cujas principais críticas são a de manutenção da desigualdade entre campo e cidade, até hoje presentes no cenário russo. Da mesma maneira, a literatura russa no século XIX foi importante para aproximar a intelectualidade da população em geral, e não à toa Dostoiévski foi demonizado pela intelectualidade e prestigiado pelas diferentes classes socais. O discurso falacioso da identidade e a crítica às transformações espaciais em caráter dramático trouxeram a resistência e o cotidiano destas à tona, e possibilitou discussões políticas mais profundas como a que envolve concentração de riqueza;

3 - Dessa importância trazida da análise geográfica a uma obra ainda pouco lida pelos geógrafos, mostra com clareza que a intersecção entre Literatura e Geografia é deveras necessária para o aprimoramento da apreensão científica, seja na relação com as categorias da análise científica quanto de todos os processos responsáveis pelas transformações ditadas e analisadas criticamente pelos autores e obras. Tal análise, contudo, não deve ser necessariamente somente a um espaço próprio da geografia, como geografia da literatura ou geografia cultural, mas trazer elementos e conceitos próprios de todas as amplitudes da geografia e da análise do espaço. Uma metodologia de análise da narrativa literária que absorva o cotidiano, mais do que presente em narrativas clássicas tocaria mais profundo no nosso intrínseco papel de pesquisador, professor e colaborador a esta ciência.

O urbano é parte constituinte do ser e do produzir na cidade. Contradições e desigualdades (in)completam a cidade com as formas e gestos do conflito inerente de seus sujeitos. A cidade se perfaz no momento em que sociedade e construção se ajeitam, se relacionam em um encontro de resistência e também de insurgência. Construir a cidade é também produzi-la em todos os seus aspectos, é também compreendê-la em todas as suas tessituras. 


\section{Notas}

1 Leituras complementares à organização do espaço mundial ajudaram muito a síntese do contexto histórico apresentado neste artigo. É na contribuição da tese de Numa Mazat (2013), que aponta a percepção do auge e da crise geopolítica russa no fim do czarismo, que mais se obteve informações a respeito.

\section{Referências}

BAKHTIN, M. Problemáticas da poética de Dostoiévski. Rio de Janeiro: Forense Universitária, 2010.

BERMAN, M. Tudo que é sólido se desmancha no ar. São Paulo: Editora Schwarcz, 1986.

BEZERRA, P. Prólogo Um romance síntese. In: DOSTOIÉVSKI, F. Os irmãos Karamázov. São Paulo: Editora 34, 2009.

CAPEL, H. La definición de lo urbano. Estudios Geográficos, Madrid, n. 138-139 (número especial de "Homenaje al Profesor Manuel de Terán”), p. 265-301, febr./ mayo 1975.

CORREAA, R. L. Estudos sobre a rede urbana. Rio de Janeiro: Bertrand Brasil, 2006.

. O espaço urbano. São Paulo: Editora Ática, 1989.

. Trajetórias geográficas. Rio de Janeiro: Bertrand Brasil, 2010.

CHRISTALLER, W. Central places in Southern Germany. Englewood Clifs: Prentice-Hall, 1966.

DELEUZE, G. Cinema 1: a imagem-movimento. Rio de Janeiro: Editora Brasiliense, 1983.

DOSTOIÉVSKI, F. Os irmãos Karamázov. São Paulo: Editora 34, 2009.

GOMIDE, B. B. Apresentação. In: . Antologia do pensamento crítico russo (1802-1901). São Paulo: Editora 34, 2013. p. 7-26.

HARVEY, D. A produção capitalista do espaço. São Paulo: Annablume, 2005.

LEFEBVRE, H. A revolução urbana. Belo Horizonte: Editora UFMG, 1999.

MARX, K. O Processo de Acumulação do Capital. In: . O Capital: crítica da economia política. São Paulo: Boitempo, 2013.

MAZAT, N. Uma análise estrutural da vulnerabilidade externa econômica e geopolítica da Rússia. Tese (Doutorado em Economia Política Internacional) Programa de Pós- Graduação em Economia Política Internacional, Universidade Federal do Rio de Janeiro, Rio de Janeiro, 2013.

MIKHAILÓVSKI, N. Um talento cruel. In: GOMIDE, B. B. Antologia do pensamento crítico russo (1802-1901). São Paulo: Editora 34, 2013. p. 425-508. 
SOUZA, M. L. de. ABC do Desenvolvimento urbano. Rio de Janeiro: Bertrand Brasil, 2011.

Isis do Mar Marques Martins - possui graduação em geografia pela Universidade Estadual do Rio de Janeiro, mestrado em geografia pela Universidade Federal Fluminense e atualmente é doutoranda em planejamento urbano e regional da Universidade Federal do Rio de Janeiro. Já atuou em gestão social no Governo do Estado do Rio de Janeiro e como analista de pesquisas da Organização das Nações Unidas. Atualmente é pesquisadora vinculada ao Núcleo Interdisciplinar de Estudos Migratórios, coordenado pelo professor Helion Póvoa Neto.

Recebido para publicação em 20 de agosto de 2017 Aceito para publicação em 27 de setembro de 2017 